\title{
Effect of the addition of egg white on the microbiological, physicochemical and sensory quality of steamed yogurt during fermentation and cold storage
}

\author{
Bouhadi Djilalii*, Hariri Ahmed¹, Benattouche Zouaoui ${ }^{1}$, El Ouissi A², Ibri Kada², \\ Belkhodja Hamzaㄹ, Bachir Raho G² \\ ${ }^{1}$ Laboratory of Bioconversion, Microbiology Engineering and Health Safety, University of Mustapha Stambouli of Mascara \\ (UN 2901), BP. 763, Sidi Said, 29000, Mascara, Algeria. \\ 2 Department of Biological Sciences, University of Mustapha Stambouli of Mascara, Algeria.
}

*Corresponding author: bouhadidjilali@yahoo.fr

Received 20 October 2020; Accepted 12 March 2021

\begin{abstract}
A B S T R A C T
Yogurt or yoghurt is one of the most popular fermented dairy products worldwide and has gained widespread consumer acceptance as a healthy food. In this study, steamed yogurt, which contained lactic ferments (Lactobacillus bulgaricus and Streptococcus thermophilus), was produced with egg white addition at various levels $(1 \%, 2 \%, 3 \%, 4 \%$ and $5 \%)$. The physicochemical, microbial and sensory analyses were determined to ascertain the quality attributes of the products. The dry matter, protein, viscosity and density values increased during storage. However, the microbiological properties of the five tested yogurt samples were within the international standards, and confirmed the safety and acceptability of the products. Steamed yogurts enriched with egg white were more preferred by panelists than the control yogurt in terms of sensory evaluation (flavor, color, taste and texture).The results indicated that the concentrations ( 2 and $3 \%$ ) of egg white could be used to produce an egg white yogurt without significant adverse effects on the physicochemical, microbial, and sensory properties.
\end{abstract}

Keywords: steamed yogurt, egg white, physicochemical, microbial, and sensory properties.

\section{И 3 В О Д}

Јогурт је један од најпопуларнијих ферментисаних млечних производа широм света и широко је прихваћен од стране потрошача као здрава храна. У овој студији, јогурт на пари, који је садржавао млечне ферменте (Lactobacillus bulgaricus и Streptococcus thermophilus), је произведен са додатком беланца у различитим концентрацијама (1\%, 2\%, 3\%, 4\% и 5\%). Урађене су физичко-хемијске, микробне и сензорне анализе како би се утврдиле особине квалитета производа. Вредности садржаја суве материје, протеина, вискозности и густине повећале су се током складиштења. Међутим, микробиолошка својства пет тестираних узорака јогурта била су у складу са међународним стандардима и потврдила су сигурност и прихватљивост производа. Конзументи су боље оценили парене јогурте обогаћени беланцем од контролног јогурта у смислу сензорних својстава (мирис, боја, укус и текстура). Резултати су показали да се концентрације беланца (2 и 3\%) могу користити за производњу јогурт од беланаца без значајних штетних ефеката на физичко-хемијска, микробна и сензорна својства.

Кључне речи: јогурт на пари, беланце, физичко-хемијске, микробиолошке и сензорне особине.

\section{Introduction}

Fermented milk products include a range of dairy products such as yogurt, fermented or cultured milk, acidophilus milk, kefir, kumis, curd, buttermilk, and sweet acidophilus milk obtained by the fermentation of milk by specific microorganisms (Oliveira, 2014). Among all fermented milk products, yogurt is undoubtedly the best known and most commonly consumed in the world (Sani et al., 2019). It is considered health food with high digestibility and good nutritive value(Kaur et al., 2017), and is appreciated for its taste, flavor and texture (Macit and Bakirci, 2017). It can be consumed as a complete lunch, breakfast, dinner, between-meal snack, as a beverage, or with many vegetable dishes, at any time of the day (Yildiz,
2016). In several countries, yogurt is consumed as a dessert (Yildirim et al., 2014). It is enjoyed by almost all age groups (Luckow et al., 2005), and is recommended for persons having diseases such as irritable bowel movement, inflammatory bowel syndrome and lactose intolerance (Hattingh and Viljoen, 2001).

It is produced by the fermentation of milk by two starter cultures, Streptococcus salivarius ssp. thermophilusand Lactobacillus delbrueckii ssp. bulgaricus (Rahman et al., 2016). Further, some ingredients can be added to yogurt. Several studies reported prebiotic fortification by adding dietary fibers which are found in the cell wall of vegetables, fruits or cereals to yogurt (Staffolo et al., 2004; Min et al., 2012; Dabija et al., 2018). Generally, yogurt drinks are flavored with natural or artificial fruit pieces or fruit 
juices according to consumer preferences which are varied from country to country (Gunawardhana et al., 2016). Fruits as well as vegetables are rich sources of antioxidants or other bioactive compounds that can be used to fortify yogurt (Dal Bello et al., 2015; Gad et al., 2015; Fernandez and Marette, 2017).Current market and competitive dynamics require manufacturers and the food industry to introduce new products. On the other hand, some foods and their by-products have gained the attention of researchers and industrials for their nutritional values and technological properties. Among them, egg products, which are rich in proteins, vitamins and minerals, are used (Tan et al., 2012; Miranda et al., 2015, 2019). Eggs have become important and desirable ingredients to the food industry due to their functional properties. Egg whites are widely used in various food formulations because of their foaming properties and heat gelling ability, while egg yolk serves as an emulsifyingagent (Sikorski, 2002; Hoppe, 2010; Koc et al., 2011). The use of these substances together or separately can be very interesting, given their nutritional value and functional properties. This study was carried out to develop yogurt with added egg whites and to examine the effects of this addition on the physicochemical, microbial and sensory properties of yogurt.

\section{Materials and methods}

Five different concentrations of reconstituted milk from whole milk powder containing $33 \mathrm{~g}$ of protein in 1 liter of milk, viz. 140, 130, 120, 110 and 100g/L (Table 1 ), were used for the preparation of yogurt samples in this experiment.

\subsection{Lactic ferments}

A freeze-dried spinning strain known industrially as fermenting yogurt spinning «F.Y.F» was used as a lactic ferment.

\subsection{References to lactic ferments used}

\author{
YC-X16 \\ YO-Flex \\ Freeze-dried lacto culture
}

Table 1.

Recipes for preparing yogurt samples

$\begin{array}{lcc} & \text { Milk powder g L }{ }^{-1} & \begin{array}{c}\text { Egg white } \\ \left(\mathrm{g} \mathrm{L}^{-1}\right)\end{array} \\ 1 \% \mathrm{EW} & 140 & 05 \\ 2 \% \mathrm{EW} & 130 & 10 \\ 3 \% \mathrm{EW} & 120 & 15 \\ 4 \% \mathrm{EW} & 110 & 20 \\ 5 \% \mathrm{EW} & 100 & 37 \\ \text { Control } & 140 & -\end{array}$

\subsection{Compositional analysis}

The physicochemical characteristics of the samples were evaluated as follows:

1) The $\mathrm{pH}$ of yogurt was measured using a digital pH-meter (SMART SENSOR AS218 PH-metar). Titratable acidity, ${ }^{\circ} \mathrm{D}$ (Dornic degree), was measured by
For direct vat set (DVS) thermophilic lactic culture (Streptococcus thermophilus, Lactobacillus bulcaricus)

Package size 50L

DOM: $30 / 01 / 20$

Storage at $-18^{\circ} \mathrm{C}$

With each preparation, we added, in ascending order, five concentrations of egg white separated from the egg $(5,10,15,20$, and $37 \mathrm{~g} / \mathrm{L})$, while keeping a constant sugar concentration of $80 \mathrm{~g} / \mathrm{L}$. After maturation, the samples were placed in the cold, at $4^{\circ} \mathrm{C}$, the storage temperature that stops or reduces bacterial activity and consequently fermentation. We prepared 440 jars of yogurt (40 jars for each concentration), 20 jars for physicochemical and microbiological analyses and the other for sensory evaluation.

We evaluated the physicochemical and organoleptic quality of yogurt prepared for one month. During this period, we took five samples $(1,7,15,22$ and 28 days). For each sample we analyzed the physicochemical and microbiological quality and then evaluated the organoleptic quality of these samples.

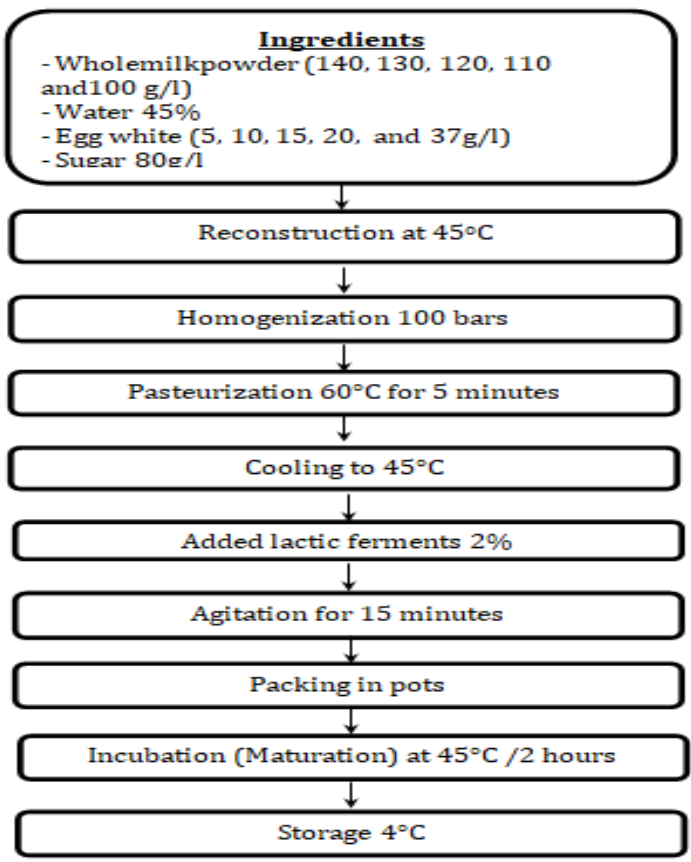

Figure 1. Yogurt preparation diagram

$\begin{array}{ccc}\text { Sugar } \mathrm{g} \mathrm{L}^{-1} & \begin{array}{c}\text { Dose of ferments } \\ \%\end{array} & \begin{array}{c}\text { Maturation time } \\ \text { (h) }\end{array} \\ 80 & 02 & 2 \\ 80 & 02 & 2 \\ 80 & 02 & 2 \\ 80 & 02 & 2 \\ 80 & 02 & 2 \\ 80 & 02 & 2\end{array}$

titrating $10 \mathrm{~g}$ of sample with $0.1 \mathrm{~N} \mathrm{NaOH}$ using phenolphthalein as indicator. Dry matter content was calculated after evaporation of the water present in the samples placed in an oven $\left(105^{\circ} \mathrm{C}\right.$ ) for $48 \mathrm{~h}$ (until constant mass was obtained). The total fat and lactose contents of the milk and samples were determined by the Gerber and Bertrand methods (Wehr and Frank, 
2004). The formaldehyde titration method was used to determine the total protein content of yogurt (Ceirwyn, 1999). Total ash content was determined by incineration at $550^{\circ} \mathrm{C}$ for $3 \mathrm{~h}$.

\subsection{Microbiological methods}

\subsubsection{Total viable count and coliform bacteria}

For microbial analysis, desoxycholate lactose agar and violet red bile lactose agar (VRBL) were used to determine total and fecal coliform counts, respectively, using the pour-plate and overlay technique. Incubations were for 24 to $48 \mathrm{~h}$ at 37 and $44^{\circ} \mathrm{C}$ (ANON, 2000).

\subsubsection{Detection of Staphylococcus aureus}

Staphylococcus aureus counts were determined on Giolitti Cantoni and Chapman agar. The plates were incubated for 24 to $48 \mathrm{~h}$ at $37^{\circ} \mathrm{C}$ (Mossel et al., 1992).

\subsubsection{Detection of Salmonella}

Dilutions were placed on Salmonella Shigella (SS) agar and incubated for 24 to $48 \mathrm{~h}$ at $37^{\circ} \mathrm{C}$, after enrichment in SFB medium for 24 to $48 \mathrm{~h}$ at $37^{\circ} \mathrm{C}$ (Mossel et al., 1992).

\subsubsection{Total yeasts and molds}

Total yeasts and molds were determined on potato dextrose agar (PDA) to which an antibacterial agent (oxytetracycline) was incorporated and incubated for three to five days at $25^{\circ} \mathrm{C}$ (Mossel et al., 1992).

\subsection{Sensory evaluation}

The flavor, taste and texture of all yogurt samples were evaluated sensorially by a non-trained panel of ten students of the Mascara University, Mascara, Algeria using a five-point score system (1, excellent; 2 , good; 3, acceptable; 4, bad; 5, insupportable) (Metin, 2006). The sensory profiles were conducted on coded samples served in plastic cups and freeze stored after 28 days of storage. The results of these parameters can be treated by the use of statistical analyses (analysis of variance and correspondence analysis).

\section{Results and discussions}

\subsection{Results of physicochemical analyses of parboiled steamed yogurt with egg white}

\subsubsection{Acidity and hydrogen potential $(\mathrm{pH})$}

Table 1 shows a significant increase in the acidity of yogurt samples during their storage. These values are comparable to those found by Gurmeet and Kasiviswanathan (2008) for calcium-enriched fruit yogurt. The comparison of samples revealed that the evolution of acidity was slightly higher in the control yogurt than in the other yogurts in which different doses of egg white were added. The evolution of acidity can be reduced by the addition of egg white, which can help to achieve a firmer texture medium, which is therefore more hostile to the development of fermentative microorganisms, which are primarily responsible for the evolution of this acidity. The change in acidity was confirmed by the $\mathrm{pH}$ analysis. Indeed, it seems very clear that the addition of egg white can slow down the reduction of the $\mathrm{pH}$ value of the finished product.

\subsubsection{Total dry matter content}

Samples of steamed yogurt enriched with egg white showed a decrease in total dry matter during storage. The dry matter was represented mainly by the sugar, proteins, mineral salts, fats and vitamins of the yoghurt (Hariri and Ouis, 2020). This decrease may be due to these chemical compounds produce $d$ by lactic ferments as a source of nutrients and energy for the metabolism of these microorganisms (Abdalla et al., 1993; Omer and Eltinay, 2009).

\subsubsection{Ash}

The results in Table 2 showed a decrease in mineral elements in the yogurts containing the different doses of egg white and the control sample during the entire storage period (28 days). This may be caused by interactions between the mineral fraction and the other components (proteins, lipids, etc.). Our results are similar to those of Bourdichon (2012).

\subsubsection{Proteins}

For proteins, it was noted that the positive evolution of the protein level was more pronounced in yogurt enriched with egg white compared to control yogurt. Egg white represented an additive source of protein. The protein content appeared to decrease during the 21 days of storage. These values are in line with the standard recommended by JORA and FIL (1998), which recommend levels of 4-D and 5\%, respectively.

\subsubsection{Sugar}

Generally, lactic acid bacteria use lactose as their energy resource and produce lactic acid (Hartati et al., 2012). After hydrolysis, at the end of incubation, glucose was used preferentially by the microbiota, because carbohydrates are in the majority in the albumen either in the free state or combined with proteins and lipids. From the tenth day of storage, there was a decrease, which can be explained by the use of sugars by lactic acid bacteria, which transform lactose into galactose and glucose. The latter turns into pyruvic acid, and then into lactic acid. The amount of galactose increased to 1 to 1.5 compared with that of glucose.

It also contains free glucose, which is the first source of energy that can be used by the lactic bacteria (Hariri and Ouis, 2020). Our values are lower than those indicated by (Bachir Raho and Benattouche, 2013), which were 19.5 for yogurts enriched with rosemary essential oils. 
Table 2.

Physicochemical changes of yogurt samples during storage for 28 days at $4^{\circ} \mathrm{C}$.

Storage period (days)

\begin{tabular}{|c|c|c|c|c|c|c|}
\hline Parameter & & 1 & 7 & 15 & 22 & 28 \\
\hline \multirow{6}{*}{$\mathrm{pH}$} & $1 \% \mathrm{EW}$ & 4.62 & 4.40 & 4.29 & 4.19 & 4.07 \\
\hline & $2 \% \mathrm{EW}$ & 4.70 & 4.53 & 4.30 & 4.21 & 4.10 \\
\hline & $3 \% \mathrm{EW}$ & 4.58 & 4.36 & 4.25 & 4.15 & 4.05 \\
\hline & $4 \% \mathrm{EW}$ & 4.80 & 4.63 & 4.47 & 4.31 & 4.20 \\
\hline & $5 \% \mathrm{EW}$ & 4.74 & 4.57 & 4.34 & 4.24 & 4.13 \\
\hline & Control & 4.53 & 4,30 & 4.20 & 4.10 & 4.02 \\
\hline \multirow{6}{*}{ Titratable acidity $\left({ }^{\circ} \mathrm{D}\right)$} & $1 \% \mathrm{EW}$ & 78 & 86 & 95 & 106 & 112 \\
\hline & $2 \% \mathrm{EW}$ & 77 & 85 & 94 & 104 & 110 \\
\hline & $3 \% \mathrm{EW}$ & 79 & 87 & 97 & 107 & 115 \\
\hline & $4 \% \mathrm{EW}$ & 75 & 82 & 90 & 102 & 109 \\
\hline & $5 \% \mathrm{EW}$ & 76 & 83 & 91 & 100 & 106 \\
\hline & Control & 80 & 89 & 99 & 408 & 118 \\
\hline \multirow{6}{*}{ Dry matter (\%) } & $1 \% \mathrm{EW}$ & 26.9 & 21.3 & 17.5 & 15.2 & 14.6 \\
\hline & $2 \% \mathrm{EW}$ & 26.4 & 19.0 & 16.8 & 14.6 & 13.9 \\
\hline & $3 \% \mathrm{EW}$ & 26.5 & 21.6 & 18.7 & 16.5 & 14.8 \\
\hline & $4 \% \mathrm{EW}$ & 26.7 & 22.1 & 18.4 & 16.8 & 14.6 \\
\hline & $5 \% \mathrm{EW}$ & 26.9 & 22.4 & 19.8 & 17.5 & 15.76 \\
\hline & Control & 26.4 & 19.8 & 17.0 & 14.9 & 13.5 \\
\hline \multirow{6}{*}{ Ash (5\%) } & $1 \% \mathrm{EW}$ & 0.20 & 0.15 & 0.11 & 0.09 & 0.07 \\
\hline & $2 \% \mathrm{EW}$ & 0.19 & 0.14 & 0.10 & 0.08 & 0.07 \\
\hline & $3 \% \mathrm{EW}$ & 0.17 & 0.13 & 0.09 & 0.07 & 0.05 \\
\hline & $4 \% \mathrm{EW}$ & 0.15 & 0.12 & 0.09 & 0.07 & 0.04 \\
\hline & $5 \% \mathrm{EW}$ & 0.13 & 0.11 & 0.08 & 0.06 & 0.02 \\
\hline & Control & 0.22 & 0.16 & 0.12 & 0.10 & 0.08 \\
\hline \multirow{6}{*}{ Proteins (\%) } & $1 \% \mathrm{EW}$ & 4.06 & 3.77 & 3.46 & 3.05 & 2.63 \\
\hline & $2 \% \mathrm{EW}$ & 4.21 & 3.37 & 3.50 & 3.10 & 2.75 \\
\hline & $3 \% \mathrm{EW}$ & 4.59 & 3.99 & 3.36 & 3.25 & 2.84 \\
\hline & $4 \% \mathrm{EW}$ & 4.77 & 4.03 & 3.87 & 3.17 & 3.02 \\
\hline & $5 \% \mathrm{EW}$ & 4.81 & 4.11 & 3.87 & 3.45 & 3.02 \\
\hline & Control & 4.98 & 4.31 & 4.03 & 3.89 & 3.46 \\
\hline \multirow{6}{*}{ Lactose $(\%)$} & $1 \% \mathrm{EW}$ & 15.45 & 14.98 & 14.12 & 13.98 & 12.8 \\
\hline & $2 \% \mathrm{EW}$ & 15.79 & 15.02 & 13.65 & 11.5 & 10.98 \\
\hline & $3 \% \mathrm{EW}$ & 15.91 & 14.98 & 13.68 & 11.4 & 10.68 \\
\hline & $4 \% \mathrm{EW}$ & 16.57 & 13.54 & 12.5 & 10.32 & 9.87 \\
\hline & $5 \% \mathrm{EW}$ & 16.98 & 14.54 & 11.24 & 10.5 & 9.21 \\
\hline & Control & 13.6 & 11.68 & 10.31 & 9.97 & 8.11 \\
\hline
\end{tabular}

\subsection{Results of microbiological analyses}

The obtained results of the microbiological analysis showed a complete absence of total and fecal coliforms, Staphylococcus aureus, and Salmonellas in the five categories of yogurt (Table 3). These results can be explained by the respect of hygienic conditions, the effectiveness of heat treatments and the acidifying activity of the lactic ferments, which inhibited the growth of these microorganisms. The enriched yogurts had satisfactory hygienic quality and did not involve any risk of intoxication since we did not detect the presence of $S$. aureus. Yeasts and molds appeared in the first week of storage $(<10$ yeasts $/ \mathrm{mL})$, then this number increased to $<40$ yeasts/mL during the last week of storage for $1 \% \mathrm{EW}, 2 \% \mathrm{EW}, 3 \% \mathrm{EW}$ and $5 \% \mathrm{EW}$. Our results for all yogurts prepared in line are in accordance with the findings of several authors (Ahmed et al., 2018; Bachir Raho et al., 2013). 
Table 3.

Results of microbiological analyses of yogurt samples during storage for 28 days at $4{ }^{\circ} \mathrm{C}$.

Storage period (days)

\begin{tabular}{|c|c|c|c|c|c|c|}
\hline \multicolumn{2}{|c|}{ Parameter } & 1 & 7 & 15 & 22 & 28 \\
\hline $1 \% \mathrm{EW}$ & $\begin{array}{c}\text { Total coliform } \\
\text { Fecal coliform; } \\
\text { Staphylococcus aureus } \\
\text { Salmonellae } \\
\text { Yeasts and molds }\end{array}$ & $\begin{array}{l}\text { Abs } \\
\text { Abs } \\
\text { Abs } \\
\text { Abs } \\
<10\end{array}$ & $\begin{array}{c}\text { Abs } \\
\text { Abs } \\
\text { Abs } \\
\text { Abs } \\
45\end{array}$ & $\begin{array}{l}\text { Abs } \\
\text { Abs } \\
\text { Abs } \\
\text { Abs } \\
80\end{array}$ & $\begin{array}{l}\text { Abs } \\
\text { Abs } \\
\text { Abs } \\
\text { Abs } \\
110\end{array}$ & $\begin{array}{l}\text { Abs } \\
\text { Abs } \\
\text { Abs } \\
\text { Abs } \\
2^{*} 10^{2}\end{array}$ \\
\hline $2 \% \mathrm{EW}$ & $\begin{array}{c}\text { Total coliform } \\
\text { Fecal coliform; } \\
\text { Staphylococcus aureus } \\
\text { Salmonellae } \\
\text { Yeasts and molds }\end{array}$ & $\begin{array}{l}\text { Abs } \\
\text { Abs } \\
\text { Abs } \\
\text { Abs } \\
<10\end{array}$ & $\begin{array}{c}\text { Abs } \\
\text { Abs } \\
\text { Abs } \\
\text { Abs } \\
41\end{array}$ & $\begin{array}{l}\text { Abs } \\
\text { Abs } \\
\text { Abs } \\
\text { Abs } \\
64\end{array}$ & $\begin{array}{l}\text { Abs } \\
\text { Abs } \\
\text { Abs } \\
\text { Abs } \\
120\end{array}$ & $\begin{array}{l}\text { Abs } \\
\text { Abs } \\
\text { Abs } \\
\text { Abs } \\
180\end{array}$ \\
\hline $3 \% \mathrm{EW}$ & $\begin{array}{c}\text { Total coliform } \\
\text { Fecal coliform; } \\
\text { Staphylococcus aureus } \\
\text { Salmonellae } \\
\text { Yeasts and molds }\end{array}$ & $\begin{array}{l}\text { Abs } \\
\text { Abs } \\
\text { Abs } \\
\text { Abs } \\
<10\end{array}$ & $\begin{array}{c}\text { Abs } \\
\text { Abs } \\
\text { Abs } \\
\text { Abs } \\
36\end{array}$ & $\begin{array}{l}\text { Abs } \\
\text { Abs } \\
\text { Abs } \\
\text { Abs } \\
67\end{array}$ & $\begin{array}{l}\text { Abs } \\
\text { Abs } \\
\text { Abs } \\
\text { Abs } \\
90\end{array}$ & $\begin{array}{l}\text { Abs } \\
\text { Abs } \\
\text { Abs } \\
\text { Abs } \\
102\end{array}$ \\
\hline $4 \% \mathrm{EW}$ & $\begin{array}{c}\text { Total coliform } \\
\text { Fecal coliform; } \\
\text { Staphylococcus aureus } \\
\text { Salmonellae } \\
\text { Yeasts and molds }\end{array}$ & $\begin{array}{l}\text { Abs } \\
\text { Abs } \\
\text { Abs } \\
\text { Abs } \\
<10\end{array}$ & $\begin{array}{c}\text { Abs } \\
\text { Abs } \\
\text { Abs } \\
\text { Abs } \\
32\end{array}$ & $\begin{array}{l}\text { Abs } \\
\text { Abs } \\
\text { Abs } \\
\text { Abs } \\
62\end{array}$ & $\begin{array}{l}\text { Abs } \\
\text { Abs } \\
\text { Abs } \\
\text { Abs } \\
88\end{array}$ & $\begin{array}{l}\text { Abs } \\
\text { Abs } \\
\text { Abs } \\
\text { Abs } \\
98\end{array}$ \\
\hline $5 \% \mathrm{EW}$ & $\begin{array}{c}\text { Total coliform } \\
\text { Fecal coliform; } \\
\text { Staphylococcus aureus } \\
\text { Salmonella } \\
\text { Yeasts and molds }\end{array}$ & $\begin{array}{l}\text { Abs } \\
\text { Abs } \\
\text { Abs } \\
\text { Abs } \\
<10\end{array}$ & $\begin{array}{c}\text { Abs } \\
\text { Abs } \\
\text { Abs } \\
\text { Abs } \\
20\end{array}$ & $\begin{array}{l}\text { Abs } \\
\text { Abs } \\
\text { Abs } \\
\text { Abs } \\
42\end{array}$ & $\begin{array}{c}\text { Abs } \\
\text { Abs } \\
\text { Abs } \\
\text { Abs } \\
88\end{array}$ & $\begin{array}{l}\text { Abs } \\
\text { Abs } \\
\text { Abs } \\
\text { Abs } \\
106\end{array}$ \\
\hline Control & $\begin{array}{c}\text { Total coliform } \\
\text { Fecal coliform; } \\
\text { Staphylococcus aureus } \\
\text { Salmonellae } \\
\text { Yeasts and molds }\end{array}$ & $\begin{array}{l}\text { Abs } \\
\text { Abs } \\
\text { Abs } \\
\text { Abs } \\
<10\end{array}$ & $\begin{array}{l}\text { Abs } \\
\text { Abs } \\
\text { Abs } \\
\text { Abs } \\
116\end{array}$ & $\begin{array}{c}\text { Abs } \\
\text { Abs } \\
\text { Abs } \\
\text { Abs } \\
11^{*} 10^{2}\end{array}$ & $\begin{array}{l}\text { Abs } \\
\text { Abs } \\
\text { Abs } \\
\text { Abs } \\
68 * 10^{2}\end{array}$ & $\begin{array}{c}\text { Abs } \\
\text { Abs } \\
\text { Abs } \\
\text { Abs } \\
12^{*} 10^{3}\end{array}$ \\
\hline
\end{tabular}

\subsection{Sensory characteristics}

As regards sensory characteristics, the acidity, flavor and texture of the yogurts were examined. According to the results presented in Table 3, yogurt + $2 \% \mathrm{EW}$ was best appreciated by the members of the panel and had the best acidity, texture and flavor, followed by the yogurts enriched with lower concentrations of $1 \% \mathrm{EW}$. It is obvious that the addition of egg white promoted a much more appreciable texture in steamed yogurt, and its gelling and coagulating characteristics gave more firmness and texture to the final product. The proteins of egg white induced this coagulation; heat reduced the risk of softer texture appearance or the phenomenon of whey separation (synerisis), which are generally undesirable manufacturing defects. Yogurt is characterized as a fermented milk product with a refreshing flavor, a slight sour taste and a smooth viscous gel. The flavor scores showed that samples with $4 \%$ and 5\% EW took the lowest percentage compared to $3 \%$ and $2 \%$ EW added to yogurt, indicating that the increase in the mass fraction of egg white had a negative effect. These sensory properties offer quality control criteria, and therefore, yogurt should be examined for acidity, taste, and texture. Yogurt flavor (acidity)depends on the presence of lactic acid and other flavoring compounds produced by starter culture during the fermentation process. The texture of yogurt is affected by the specific rate of acid production during the fermentation process, as well as by the fat content and the presence of stabilizing agents such as gelatin, milk solids, and sugar. Heating the mix denatures whey proteins, increases the water-holding capacity of milk protein, and reduces syneresis in yogurt. 
Table 4.

Sensory quality of yogurt samples after 28 days of storage

\begin{tabular}{|c|c|c|c|c|c|c|}
\hline Parameter & & Excellent (\%) & Good (\%) & Acceptable (\%) & Bad (\%) & Insupportable (\%) \\
\hline Texture & $\begin{array}{l}1 \% \mathrm{EW} \\
2 \% \mathrm{EW} \\
3 \% \mathrm{EW} \\
4 \% \mathrm{EW} \\
5 \% \mathrm{EW} \\
\text { Control }\end{array}$ & $\begin{array}{c}40 \\
26.66 \\
20 \\
33.33 \\
13.33 \\
6.66 \\
\end{array}$ & $\begin{array}{c}46.66 \\
53.33 \\
46.66 \\
26.66 \\
40 \\
53.33\end{array}$ & $\begin{array}{c}13.33 \\
20 \\
33.33 \\
40 \\
33.33 \\
20\end{array}$ & $\begin{array}{c}00 \\
00 \\
00 \\
00 \\
13.33 \\
20\end{array}$ & $\begin{array}{c}00 \\
00 \\
00 \\
00 \\
4.13 \\
00\end{array}$ \\
\hline Flavor & $\begin{array}{l}1 \% \mathrm{EW} \\
2 \% \mathrm{EW} \\
3 \% \mathrm{EW} \\
4 \% \mathrm{EW} \\
5 \% \mathrm{EW} \\
\text { Control }\end{array}$ & $\begin{array}{c}20 \\
33.33 \\
00 \\
13.33 \\
6.66 \\
00 \\
\end{array}$ & $\begin{array}{c}33.33 \\
33.33 \\
40 \\
33.33 \\
13.33 \\
33.33 \\
\end{array}$ & $\begin{array}{c}33.33 \\
33.33 \\
33.33 \\
40 \\
46.66 \\
60 \\
\end{array}$ & $\begin{array}{c}13.33 \\
00 \\
20 \\
6.66 \\
20 \\
6.66 \\
\end{array}$ & $\begin{array}{c}00 \\
00 \\
6.66 \\
6.66 \\
13.33 \\
00 \\
\end{array}$ \\
\hline Acidity & $\begin{array}{l}1 \% \mathrm{EW} \\
2 \% \mathrm{EW} \\
3 \% \mathrm{EW} \\
4 \% \mathrm{EW} \\
5 \% \mathrm{EW} \\
\text { Control }\end{array}$ & $\begin{array}{c}00 \\
33.33 \\
00 \\
00 \\
6.66 \\
00\end{array}$ & $\begin{array}{c}46.66 \\
40 \\
53.33 \\
53.33 \\
26.66 \\
13.33\end{array}$ & $\begin{array}{c}53.33 \\
6.66 \\
46.66 \\
46.66 \\
26.66 \\
53.33\end{array}$ & $\begin{array}{c}00 \\
20 \\
00 \\
00 \\
33.33 \\
33.33\end{array}$ & $\begin{array}{c}00 \\
00 \\
00 \\
00 \\
6.66 \\
00\end{array}$ \\
\hline
\end{tabular}

The statistical study (analysis of variance and AFC correspondence analysis) confirmed the obtained organoleptic results. The tasting jury members appreciated the flavor, acidity and texture of the $2 \%$ egg white sample the most.

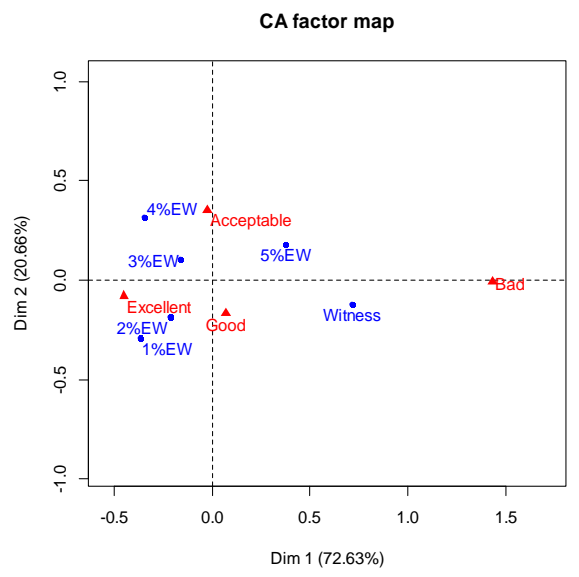

Figure 2. Biplot representation (of variables and individuals) of texture

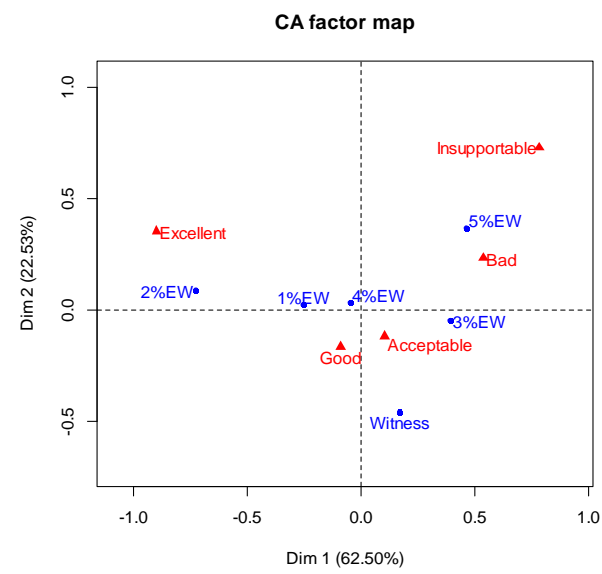

Figure 3. Biplot representation (of variables and individuals) of flavor

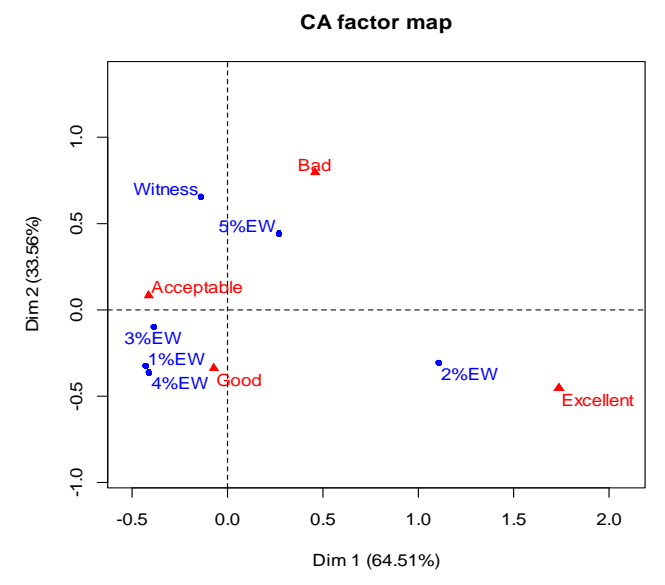

Figure 4. Biplot representation (of variables and individuals) of acidity

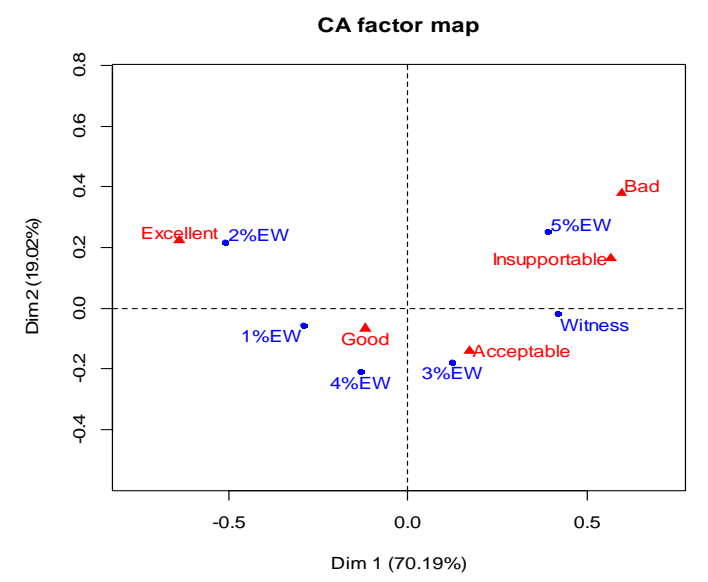

Figure 5. Biplot representation (of variables and individuals) of three parameters (flavor, texture and acidity) 


\section{Conclusions}

With the aim of improving yogurt quality, dairy industries incorporate chemical texturing agents. In this research, we used natural additives to take advantage of their nutritional richness and functional properties in order to satisfy the consumer's curiosity with a food of new taste and new presentation. The presence of egg white in steamed yogurt seems to be an agent presenting the absence of microorganisms such as yeasts and molds, as well as total coliforms and total number of microorganisms. For the physicochemical aspect, the steamed yogurt obtained after the addition of egg white appeared to conform to the standard as it had very high levels of dry matter and proteins. The sensory analyses confirmed the very positive effect of egg white on the sensory characteristics of yogurt, especially on the texture, taste and acidity of the finished products. Finally, it can be observed that the incorporation of egg white can solve manufacturing problems called manufacturing accidents, especially those concerning texture and coagulate separation.

\section{Acknowledgment}

The authors would like to express their sincere gratitude to all staff of the department of Biology, University of Mustapha Stambouli, Mascara.

\section{Declaration of competing interest}

The authors declare that they had no conflict of interests.

\section{References}

Abdalla, O.M., Christen, G.L., Davidson, P.M. (1993). Chemical composition of and Listeria monocytogenes survival in white pickled cheese. Journal of Food Protection, 56, 841846.

Ahmed, H., Nawel, O., Djilali, B., Zouaoui, B. (2018). Characterization of the quality of the steamed yoghurts enriched by date's flesh and date powder variety H'loua. Banat's Journal of Biotechnology DOI: 10.7904/20684738-IX(17)-31

ANON (2000). Approved Methods of Analysis.10th Ed.The American Association of Cereal Chemists (AACC).St. Paul, MN.

BachirRaho, G., Benattouche, Z, (2013). Evaluation of the quality of steamed yogurt treated by Lavandula and Chamaemelum species essential oils. Journal of Medicinal Plants Research, 7(42), 3121-3126.

Bourdichon, F., Casaregola, S., Farrokh, C., Frisvad, J.C., Gerds, M.L., Hammes, W.P., Harnett, J., Huys, G., Laulund, S., Ouwehand, A., Powell, I.B., Prajapati, J.B., Seto, Y., TerSchure, E., Van Boven, A., Vankerckhoven, V., Zgoda, A., Tuijtelaars, S., Hansen, E.B. (2012. Food fermentations: microorganisms with technological beneficial use. International Journal of Food Microbiology, 154(3):87-97.

Ceirwyn, S.J. (1999). Analytical chemistry of foods. Edition Chapman and Hall, New York. P. 90.

Dabija, A., Codină, G.G., Gâtlan, A.M, Rusu, L. (2018). Quality assessment of yogurt enriched with different types of fibers. CyTA - Journal of Food, 16(1), 859-867.

Dal Bello, B., Torri, L., Piochi, M. Zeppa, G. (2015). Healthy yogurt fortified with n-3 fatty acids from vegetable sources. Journal of Dairy Science, 98(12), 8375-8385.

Fernandez, M.A., Marette, A. (2017). Potential Health Benefits of Combining Yogurt and Fruits Based on Their Probiotic and Prebiotic Properties. Advances in Nutrition, 8(1), 155S-164S.
Gad, S.A., Ghita, E.I., El-Din Hala, M.F, Badran, S.M.A., ElMessery, T.M. (2015). Evaluation yogurt fortified with vegetable and fruit juice as a natural source of antioxidant. International Journal of Food and Nutritional Sciences, 4(3), 21-28.

Gunawardhana, W.A.D.C., Dilrukshi, H.N.N. (2016). Development of yoghurt drink enriched with avocado pulp. International Journal of Advanced Scientific Research and Management, 1, 97-102.

Hariri, A., Ouis, N. (2020). Effect of volatile oils from Petroselinum crispum and Foeniculum vulgare on the quality and shelf-life of steamed yoghurts. Algerian Journal of Natural Products, 8(1), 723 - 731.

Hartati, A.I., Pramono, Y.B., Legowo, A.M. (2012). Lactose and reduction sugar concentrations, $\mathrm{pH}$ and the sourness of date flavored yogurt drink as probiotic beverage. Journal of Applied Food Technology, 1, 1-3.

Hattingh, L.A., Viljoen, B.C. (2001). Yogurt as Probiotic Carrier Food. International Dairy Journal, 11(1), 1-17.

Hoppe, A. (2010). Examination of egg white proteins and effects of high pressure on select physical and functional properties. M.S. thesis, University of Nebraska Lincoln, Lincoln, NE, USA,

JORA. N³5. 1998. Arête interministériel de 23 juillet 1994. Relatif aux spécificationsmicrobiologiques de certainesdenréesalimentaires. Journal Officiel de la RépubliqueAlgérienne.

Kaur, R., Kaur, G., Rima Mishra, S.K., Panwar, H., Mishra, K.K., Brar, G.S. (2017). Yogurt: A nature's wonder for mankind. International Journal of Fermented Foods, 6(1), 57- 69.

Koc, M., Koc, B., Susyal, G., SakinYılmazer, M., Kaymak Ertekin, F., Bağdatlığlu, N. (2011). Functional and physicochemical properties of whole egg powder: effect of spray drying conditions. Journal of Food and Science Technology, 48(2), 141-149.

Luckow, T., Moskowitz, H.R., Beckley, J., Hirsch J., Genchi S. (2005). The Four Segments of Yogurt Consumers: Preferences and Mind-Sets. Journal of Food Products Marketing, 11(1), 1-22.

Macit, E., Bakirci, I. (2017). Effect of different stablizers on quality characteristics of the set-type yogurt. African Journal of Biotechnology, 16 (46), 2142-2151.

Metin, M. (2006). Analysis Methods of Milk and Dairy products (Sensory, Physical and Chemical Analysis). Ege University Publications, Bornova.

Min, Y.W., Park, S.U., Jang, Y.S., Kim, Y.H., Rhee, P.L., Ko, S.H., Joo, N., Kim, S.I., Kim, C.H., Chang, D.K. (2012). Effect of composite yogurt enriched with acacia fiber and Bifidobacterium lactis. World Journal of Gastroenterology,18(33), 4563-4569.

Miranda, J.M., Anton, X., Redondo-Valbuena, C., Roca-Saavedra, P., Rodriguez, J.A., Lamas, A., Franco, C.M., Cepeda, A. (2015). Egg and egg-derived foods: Effects on human health and use as functional foods. Nutrients, 7(1), 70629.

Mossel, D.A.A., Visser, M., Mengerink, W.H.J. (1992). A comparison of media for the enumeration of moulds and yeasts in foods and beverages. Laboratory Practice, 11, 109-112.

Oliveira, M.N. (2014). Fermented Milks and yoghurt. In Carl A. Batt..Encyclopedia of food microbiology. 2nd. ed. London: Academic Press, 908-922.

Omer, R.H., Eltinay, A.H. (2009). Changes in Chemical Composition of Camel's Raw Milk during Storage. Pakistan Journal of Nutrition, 8, 607-610.

Rahman, R., Alam, M.Z., Mukta, S. (2016). Studies on yogurt production using Lactobacillus bulgaricus and Streptococcus thermophilus isolated from market yogurt. Journal of Sylhet Agricultural University, 3(2), 307-313.

Réhault-Godbert, S., Guyot, N., Nys, Y. (2019). The Golden Egg: Nutritional Value, Bioactivities, and Emerging Benefits for Human Health. Nutrients, 11(3), 684.

Sani, A.M., Rahbar, M., Sheikhzadeh, M. (2019). Traditional Beverages in Different Countries: Milk-Based Beverages. Volume 9. The Science of Beverages, 239-272.

Sikorski, Z.E. (2002). Chemical and Functional Properties of Food Components, Second Edition. CRC Press, 384 pages. 
Singh, G., Muthukumarappan, K. (2008). Influence of calcium fortification on sensory, physical and rheological characteristics of fruit yogurt. LWT-Food Science and Technology, 41(7), 1145-1152.

Staffolo, M.D, Bertola, N, Martino, M, Bevilacqua, A. (2004). Influence of dietary fiber addition on sensory and rheological properties of yogurt. International Dairy Journal, 14, 263-268.

Tan, T.C., Kanyarat, K., Azhar, M.E. (2012). Evaluation of functional properties of egg white obtained from pasteurized shell egg as ingredient in angel food cake. International Food Research Journal, 19(1), 303-308.
Wehr, H.M., Frank, J.F. (2004). Standard Methods for the Examination of Dairy Products. 17th ed., pp. 327-404, American Public Health Association, Baltimore, USA, 363527.

Yildirim, Ç., Kökbaş, C., Sezer, Z., Işik, C.., Güzeler, N. (2014). Yogurt, Yogurt-Based Products and Their General Usages. Turkish Journal of Agricultural and Natural Sciences, Special Issue, 1, 1063-1066.

Yildiz, F. (2016). Development and Manufacture of Yogurt and Other Functional Dairy Products. CRC Press, 451 pages. 